\title{
Public Communication Programs for the Alexandria Refuse Collection Service
}

\author{
Hisashi OGAWA \\ Institute of Industrial Ecological Sciences, University of Occupational and Environmental Health, Japan. \\ Kitakyushu 807, Japan
}

Abstract: Public communication programs for the refuse collection service in Alexandria, Egypt, were developed and implemented in a refuse collection experiment conducted in the summer of 1985. These programs were evaluated in terms of their technical, financial and organizational feasibilities. Results indicated that the public communication programs developed were technically and financially feasible although regional and religious meetings appeared to be not as effective as expected. The major problem was found to be that no organization responsible for public communication existed in the Alexandria government. It is thus strongly recommended that such an organization be established.

Key words: public communication, refuse collection service, Alexandria.

(Received 15 February 1986)

\section{Introduction}

Operations of many public services in recent years such as water supply and sewage collection are performed with little public participation. Municipal cleansing service, however, requires much attention, understanding and cooperation of the citizens. In fact, without citizens' cooperation in meeting the refuse collection schedule, no refuse collection work is possible. Public understanding and cooperation can be obtained through public communication programs which are an essential part of municipal cleansing service (Cointreau, 1982).

The overall objective of public communication for cleansing service is, therefore, to obtain understanding and cooperation of the public. The specific aims or expected effects of public communication programs are summarized by Tanaka (1984) as follows:

(1) to ease the collection service and improve the collection efficiency,

(2) to keep streets and refuse collection stations clean and sanitary,

(3) to reduce the amount of refuse and reutilize materials through collection by separation,

(4) to ease the siting of solid waste management facilities,

(5) to make people respect cleansing works and workers, and

(6) to reduce the cost of solid waste management resulting from all the effects mentioned above.

Of these specific aims, (1) through (3) can be achieved by giving refuse handling 
instructions to citizens and campaigning for public cooperation while (4) and ( 5 ) require a long-term educational effort to arouse people's awareness of the importance of cleansing works.

Public communication programs were developed and implemented for a refuse collection experiment in Alexandria, Egypt in the summer of 1985. The refuse collection experiment was jointly conducted by a Japanese study team sent by the Japan International Cooperation Agency and the Alexandria municipal cleansing personnel. The public communication programs included in the study were those of giving instructions to the public and campaigning for public cooperation; long-term public education programs were not included since the experiment period was too short for their implementation.

The purpose of this paper is to report on the public communication programs developed for the Alexandria refuse collection service and examine the feasibility of these programs. In the following sections, a brief description of the Alexandria refuse collection service is provided, followed by the public communication programs developed in the study. Evaluation of these programs is then discussed.

\section{Refuse Collection Service in Alexandria}

Alexandria (Fig. 1) is the second most populous city in Egypt with approximately 2.6

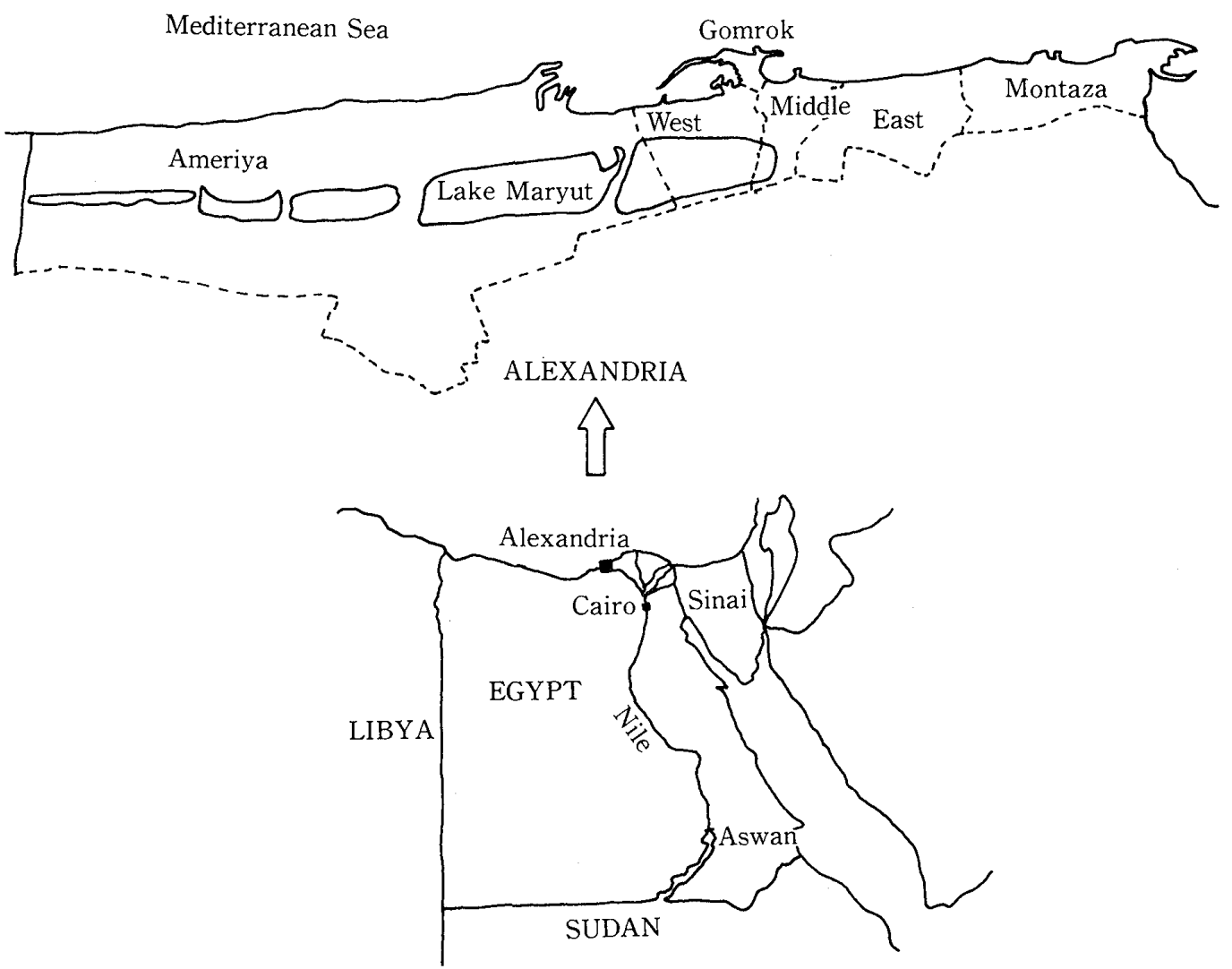

Fig. 1. Alexandria and Egypt. 
million people. The city is divided into 6 districts: Montaza, East, Middle, Gomrok, West and Ameriya Districts. The largest port in Egypt is located in the West and Gomrok Districts and the tourism industry is active on the coastal beaches facing the Mediterranean Sea. The city is situated at the western edge of the Nile delta, touching deserts in the west. The population is concentrated in the central part where people live in several-story apartment buildings (JICA, 1984).

Figure 2 presents the refuse flow in Alexandria. Refuse generated in the city receives either public or private collection service. The public service is provided by the city districts in the morning and a public association, called Association for Development of Society, in the afternoon. Although the public collection is provided daily, the service is unable to collect about ten percent of the refuse. The collection service is not efficient due to limited ability of vehicle maintenance, existence of open heap collection stations where refuse is collected by hand and baskets, and lack of public cooperation. Refuse not collected is left in open spaces, where scavengers are sometimes found.

The private service includes collection by Zabaleens (literally refuse collectors in Arabic), and self-operated collection and transportation of their waste by industries. Most factories have their own collection vehicles which are used to transport industrial wastes directly to disposal sites. Zabaleens were abundant about 10 years ago when the city provided its citizens with no refuse collection service. The number of

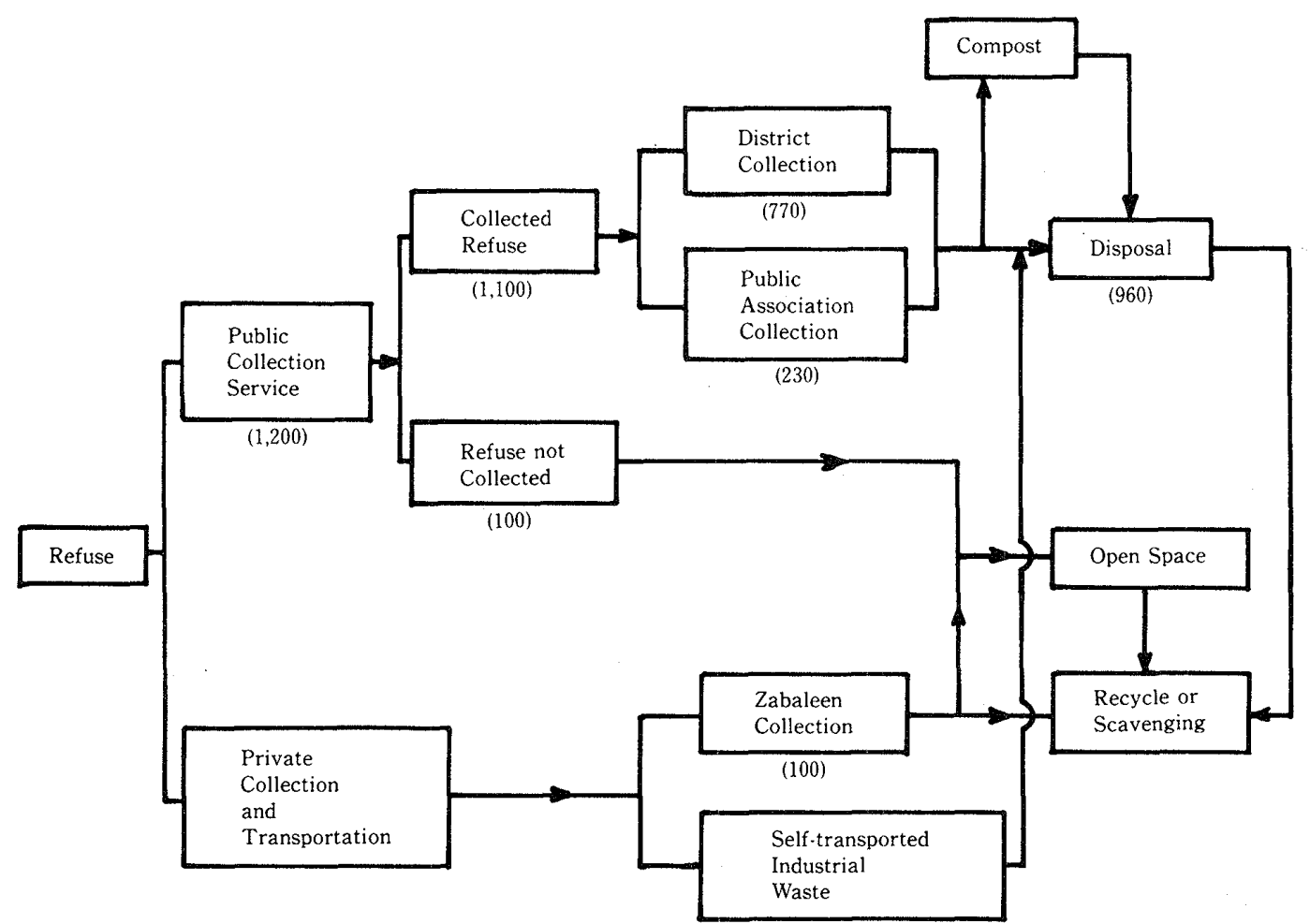

Fig. 2. Refuse flow in Alexandria. The value in parenthesis indicates the amount of refuse in ton/day. 
Zabaleens has since decreased, and they now provide only a minor collection service in the city. They use donkey-driven carts for collection and select reusable materials from the refuse collected. They often dump what is left over from their selection in open spaces, creating problems for the public service.

A compost plant which was financed by the World Bank has been operating for several months now. The capacity of the plant is 160 ton/day, but only a small amount (40 to 60 ton/day) is currently composted. Disposal of refuse is done by open dumping which creates public health problems by attracting flies and rats. One of the current disposal sites is fairly close to the city center and has the remaining life capacity of 2 to 3 years. The city is now searching for new disposal sites, especially close to the desert area.

Like many urban areas in developing countries, Alexandria suffers from two basic solid waste problems, namely public health is not well protected and the aesthetic of the city is impaired. The reasons for this include inefficient collection service, malfunctioning institutional structure, lack of technical expertise and financial capability and very limited public cooperation.

A refuse collection experiment was conducted from August 15 to September 30, 1985 to study the feasibility of a new collection method for improvement of the current practice. Three experiment areas were selected in the Middle District, differing in land use and collection container: Ibrahimeya (residential area and plastic bag container), Moharam Bey (residential area and communal container) and Mahat El Raml (commercial area and plastic bag container). A new collection schedule, including vehicle route, vehicle and manpower allocation and time and location of collection, was set for each experiment area. Public communication programs were incorporated into this experiment as an essential part to achieve a successful experiment.

\section{Public Communication Programs}

Public communication programs developed for the experiment were divided into two categories: refuse handling instructions for residents and shopowners to meet the collection schedule and campaigns to call for public participation in the experiment. These programs are described below.

\section{Refuse Handling Instructions}

The refuse handling instructions were developed after the time and location of refuse collection, possible hours for shops and offices to take out their refuse and availability of plastic bags had been determined. These instructions specified the time and location of taking out the refuse, whether to use plastic bags, and notes on the regulation prohibiting the throwing of refuse onto streets and open spaces.

The instructions were then delivered to the households and shops in the experiment 
areas in a leaflet form, henceforth called instruction leaflet. The instructions were also written on a sheet of paper, called station board, and posted at the location of refuse collection. During the experiment, the instructions were given on a person-to-person basis by visiting households and shops. The areas were also inspected and patrolled to enforce the regulation by collecting fines. The following summarizes these activities.

(1) Instruction leaflet - Instruction leaflets were delivered and explained to all the households, shops and offices in the experiment areas before the start of the experiment for 3 days from August 11 to 13, 1985 by 27 assistant workers. See Fig. 3.

(2) Station board - Station boards were put on all the containers and the walls at the collection locations in order to inform the residents and shopowners of the locations of refuse collection and the designated time and manner to take out their refuse. See Fig. 4.

(3) Inspection and patrol - Throughout the experiment period, the experiment areas were inspected and patrolled in order to guide the residents and enforce the collection rule. Inspectors visited houses and shops when necessary. For this purpose, 10 assistant workers were used in addition to District inspectors and workmasters of the experiment areas. See Fig. 5.

\section{Campaign}

Various campaign programs were developed to obtain the attention and cooperation of the people to the experiment. The media used for campaigning included radio, posters, badges, meeting at a regional society, a campaign vehicle with loudspeaker and religious meetings at mosque and church. The following list gives a summary description of each activity.

(1) Radio broadcasting by the Alexandria Radio Broadcasting Station - The experiment was announced by the radio twice a day for a few minutes from August 7 to $14,1985$.

(2) Posters and badges - Posters calling for residents' cooperation were put on building walls of the three experiment areas. Badges were given to all the personnel involved in the experiment. See Fig. 6.

(3) Regional meeting - A regional meeting was held at the Loyal Nubian Society on August 9, 1985. The meeting started at $7 \mathrm{pm}$ with the talks presented by a member of the Japanese study team and a District cleansing service personnel, followed by an open discussion session. In the meeting, opinions of both sides (citizens and the District) were exchanged. See Fig. 7.

(4) Campaign vehicle - The refuse handling instruction and calls for cooperation were delivered through a loudspeaker attached to a vehicle in the three experiment areas for a week before and the first week of the experiment. See Fig. 8.

(5) Religious meetings - A message concerning our experiment was delivered to 

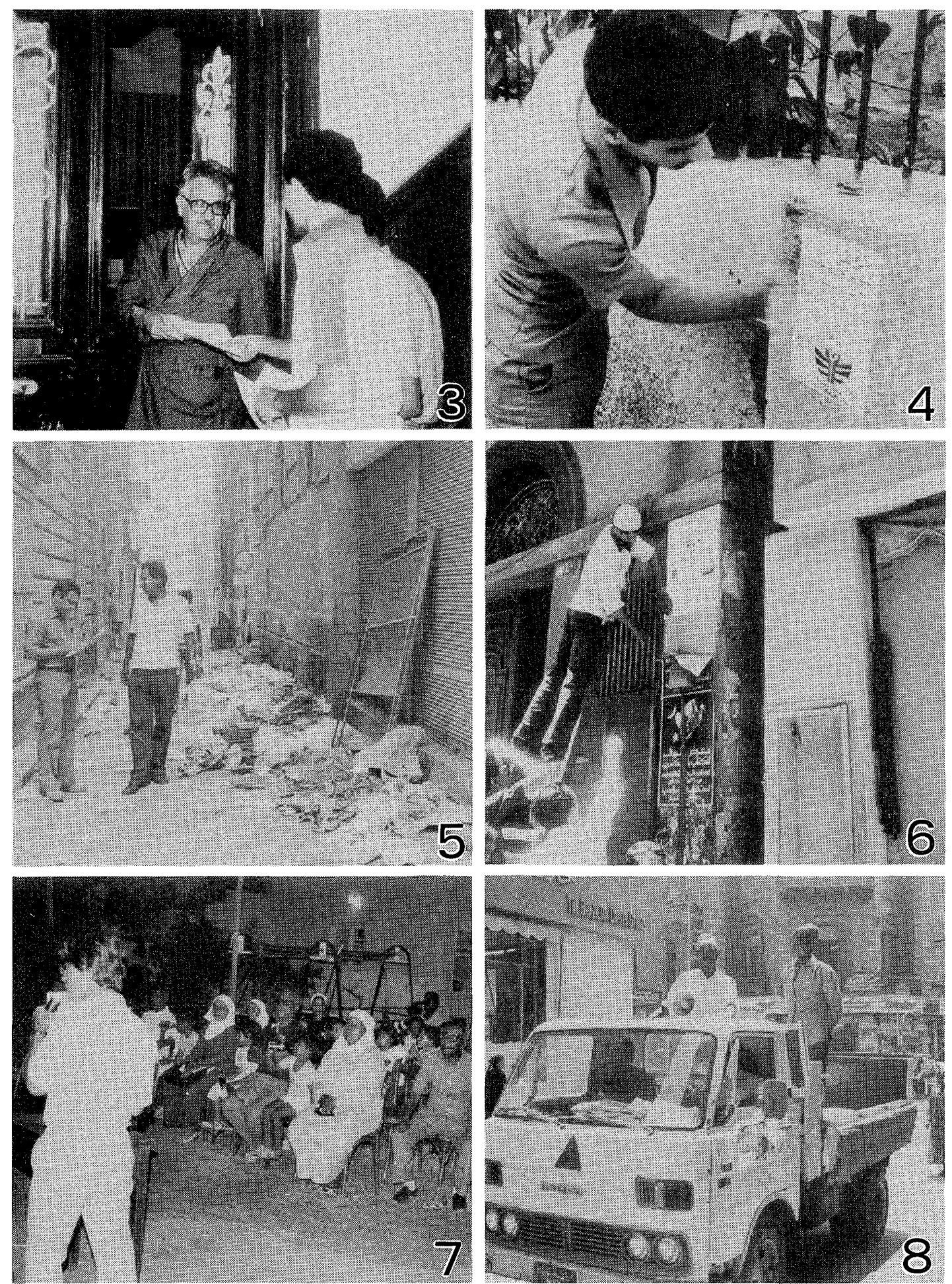

Fig. 3. Instruction leaflet delivered to a resident by assistant workers.

Fig. 4. Station board placed on a wall to indicate the location of refuse collection.

Fig. 5. Experiment area inspection and patrol by District inspectors.

Fig. 6. Poster being placed by a District cleansing worker.

Fig. 7. Talk being given to residents in a regional meeting.

Fig. 8. Campaign vehicle for experiment campaigning. Note the loudspeaker on the vehicle. 
those attending Friday prayers at mosques on August 9 and Sunday morning services at churches on August 11, 1985 in the experiment areas.

\section{Program Evaluation}

\section{Technical Feasibility}

Instruction leaflets and station boards can be fairly easily developed and implemented. Some station boards were taken off because the residents or the shops rejected the idea of having refuse collection points in front of their buildings. The person-to-person instruction and imposition of penalty through inspection and patrol were found more effective than the written materials to get an immediate response.

The radio broadcasting was done free of charge by the Alexandria Radio Broadcasting Station since this is a government-owned radio station. Most government announcements are done by the Alexandria Radio Broadcasting Station. However, the Middle East Broadcasting Station (a commercial station) is a more effective means to transfer information since more people listen to this station, although a considerable charge is required.

Posters and badges were made with no trouble. They are usually included in a campaign of this kind and attract people's attention.

Regional meetings cannot be conducted easily since it is hard to find places suitable for the meeting. In fact, the Loyal Nubian Society was the only place we could find in all the three experiment areas. The meeting itself was successful with heated debates between the cleansing authorities and the residents.

The campaign vehicle had more direct impact on people's attention than the radio broadcasting. This method was used several times before and proved to be an effective method also in this experiment.

Use of religious channels such as mosques and churches for soliciting the attention and cooperation of people is an attractive method for public communication. However, at present the government can only provide mosques and churches with campaign messages, and members of these mosques and churches decide whether and how the message is presented. Therefore the government has limited control over the effectiveness of the method.

Other possible, but not probable, methods for campaigns include newspaper advertisements, a TV program and a short film shown in movie theaters. Since the government publishes no newspaper, the cost of a newspaper advertisement is very high. The TV and movie films are also expensive, and it takes a long time to make these films for this kind of experiment. Use of existing films may be an alternative.

In summary, all the programs presented above are technically feasible in Alexandria. The person-to-person instruction through inspection and patrol and area campaigning by a campaign vehicle appeared to be effective communication techniques, 
while regional and religious meetings were found difficult to conduct.

2. Personnel and Cost

The personnel, materials and cost required to develop the public communication activities in the experiment are summarized in Table 1, except for the cost of personnel (personnel wages are provided by the central government of Egypt).

The Alexandria cleansing personnel involved in the experiment were all capable of conducting these public communication programs. However, the instructions and campaigns were carried out on an ad-hoc basis, and no organizational unit was responsible for the program development and implementation.

The materials necessary for the public communication programs were obtained in Alexandria. Plastic or metal boards are recommended for the station board material in order to avoid being torn off, although the cost will increase.

The expenditure for the program execution was kept as low as possible. For instance, a government personnel was employed to design and draw the poster and badge, and paper was used for the station board instead of plastic or metal plate. As a result, printing took most of the material cost.

In summary, the government personnel are individually capable of conducting the public communication programs, the materials for the programs are available in Alexandria, and the cost can be kept fairly low. However, an organizational unit must be established to carry out the programs.

\section{Conclusions}

Public communication programs for the refuse collection service in Alexandria were developed and implemented in a refuse collection experiment conducted in the summer of 1985. These programs were evaluated in terms of technical, organizational and financial feasibilities. These evaluations lead to the following remarks:

(1) The public communication programs developed for the Alexandria refuse collection service are technically feasible and financially not too burdensome. The senior cleansing personnel are capable of developing, implementing and evaluating public communication programs as they have already had some experience in public communication programs in the past.

(2) No organizational unit exists for public communication programs at present in Alexandria. Therefore, no long-term and continuous program can be developed and implemented. It is strongly recommended that an organizational unit for public communication be created within the government of Alexandria.

(3) In order for this organizational unit to work, all the cleansing employees from top management personnel to cleansing workers should understand the importance of public communication and cooperate with this unit in developing, im- 
Table 1. Requirements for public communication programs for the collection experiment of 1985

\begin{tabular}{|c|c|c|c|}
\hline Activity & Personnel & Materials & Cost $^{*}$ \\
\hline $\begin{array}{l}\text { Instruction leaflet } \\
\text { - Development of contents }\end{array}$ & $\begin{array}{l}2 \text { to } 3 \text { senior cleansing } \\
\text { personnel }\end{array}$ & - & - \\
\hline - Printing & (Printshop) & - & $\begin{array}{l}16 \text { 毛/1,000 papers } \\
\times 4,500 \text { papers }\end{array}$ \\
\hline $\begin{array}{l}\text { Station board } \\
\text { - Development of contents }\end{array}$ & $\begin{array}{l}2 \text { to } 3 \text { senior cleansing } \\
\text { personnel }\end{array}$ & - & - \\
\hline - Drawing & $\begin{array}{l}1 \text { artist for drawing and } \\
\text { letter writing }\end{array}$ & $\begin{array}{l}\text { Paint and paper } \\
\text { Letter writing } \\
\text { Drawing }\end{array}$ & $\begin{aligned} & 27 \text { 王 } \\
& 3 \text { 王 } \\
& 20 * \\
& 20 \mathrm{E}^{* *}\end{aligned}$ \\
\hline $\begin{array}{l}\text { - Printing } \\
\text { (covered with plastic sheets) }\end{array}$ & (Printshop) & (Color print) & $\begin{array}{c}386 \text { €E } \\
\text { (200 badges included) }\end{array}$ \\
\hline $\begin{array}{l}\text { Badge } \\
\text { - Development of idea }\end{array}$ & $\begin{array}{l}1 \text { to } 2 \text { senior cleansing } \\
\text { personnel }\end{array}$ & - & - \\
\hline - Drawing & $\begin{array}{l}1 \text { artist for drawing and } \\
\text { letter writing }\end{array}$ & (See "Station board") & (See "Station board") \\
\hline - Printing & (Printshop) & (See "Station board") & (See "Station board") \\
\hline $\begin{array}{l}\text { Poster } \\
\text { - Development of idea }\end{array}$ & $\begin{array}{l}1 \text { to } 2 \text { senior cleansing } \\
\text { personnel }\end{array}$ & - & - \\
\hline - Drawing & $\begin{array}{l}1 \text { artist for drawing and } \\
\text { letter writing }\end{array}$ & (See "Station board") & (See "Station board") \\
\hline - Printing & (Printshop) & 6 colors & $\begin{array}{l}725 \text { EE for } \\
500 \text { posters }\end{array}$ \\
\hline $\begin{array}{l}\text { Radio } \\
\text { - Development of message }\end{array}$ & $\begin{array}{l}2 \text { to } 3 \text { senior cleansing } \\
\text { personnel }\end{array}$ & - & - \\
\hline - Broadcasting & (Radio station) & - & $\begin{array}{c}0 \mathrm{EE} \\
\text { (Government station) }\end{array}$ \\
\hline $\begin{array}{l}\text { Campaign vehicle } \\
\text { - Development of message }\end{array}$ & $\begin{array}{l}2 \text { to } 3 \text { senior cleansing } \\
\text { personnel }\end{array}$ & - & - \\
\hline - Speaking & 1 cleansing personnel & $\begin{array}{l}\text { Car, loudspeaker } \\
\text { microphone } \\
\text { (District supplies) }\end{array}$ & $0 € \mathrm{E}$ \\
\hline $\begin{array}{l}\text { Religious meeting } \\
\text { - Development of message }\end{array}$ & $\begin{array}{l}2 \text { to } 3 \text { senior cleansing } \\
\text { personnel }\end{array}$ & 一 & - \\
\hline - Speaking & $\begin{array}{l}\text { Leaders at mosques and } \\
\text { churches }\end{array}$ & - & $0 € \mathrm{E}$ \\
\hline $\begin{array}{l}\text { Regional meeting } \\
\text { - Development of leaflet }\end{array}$ & $\begin{array}{l}2 \text { to } 3 \text { senior cleansing } \\
\text { personnel }\end{array}$ & - & - \\
\hline - Speaking & $\begin{array}{l}1 \text { cleansing personnel } \\
\text { and } 1 \text { JICA member }\end{array}$ & Slides, hall, chairs & $\begin{array}{c}25 \mathrm{EE} \\
\text { (for drink) }\end{array}$ \\
\hline
\end{tabular}

* 1 EE (Egyptian pound) $=1.3$ US\$.

** This is paid for the artist work. 
plementing and evaluating public communication programs. In addition to the cooperation among the cleansing people, cooperation with other organizations in the fields of health and education is necessary.

(4) The rules for handling refuse and the penalties for violation are not well understood by either the citizens or the cleansing personnel. These should be clearly understood by all concerned parties in order to carry out an effective and responsible collection service. The police should also be consulted and informed clearly of the rules and their roles in enforcing them.

\section{Acknowledgments}

This study was conducted while the author was working in Alexandria as a member of the JICA study team in the summer of 1985. He is thankful to Messrs. Ohno and Riad of the JICA study team and Mr. Ahmed Hamed of the Alexandria Follow-up Department for their assistance in this research.

\section{References}

Cointreau, S. J. (1982): Environmental Management of Urban Solid Wastes in Developing Countries. Urban Development Department, The World Bank, Washington, D. G. 214 pp. Japan International Cooperation Agency (1984): The Feasibility Study on the Plan for Refuse Collection, Treatment and Disposal in the City of Alexandria of the Arab Republic of Egypt. Progress Report (I). JICA, Tokyo. 106 pp.

Tanaka, M. (1984): On the Importance of Public Cooperation in Cleansing Administration. Gekkan Haikibutsu, 117: 39-43. (in Japanese) 
アレキサンドリア市廃棄物収集事業のための市民協力推進プログラム

小川尚

産業医科大学産業生態科学研究所

要 旨：エジプト国アレキサンドリア市における都市廃棄物収集事業改善のための市民協力推進プ ログラムが，1985 年の夏に行われた収集実験の中で計画され，実行された。この市民協 力推進プログラムは住民指導执よび収集実験協力要請キャンペーンからなり，本稿ではそ れらを個々に紹介するとともに，技術面，費用面㧍よび組織・人材面での評価を行った。 その結果，今回開発した市民協力推進プログラムのうち，地域集会およびモスクや教会に おける集会には集会場所やコミュニケーションの方法に制約があり，現状では効果的では ないことがわかったが，その他のものについては，技術扰よび費用の面でかなり効果的に 実施できることが判明した．しかし，市民協力推進プログラムを計画し，実施する組織的 主体が現在, 市政府にないため, 継続的なプログラムの運営が図れないことが重要な課題 であることがわかった、今後，このような組織体制を確立することが必要である.

J. UOEH (産業医大誌), 8 (2): 277-287 (1986) 